\title{
e-Learning: An Uphill to Reshaping Learning in Dentistry in India in the COVID-19 Pandemic Era
}

\author{
Teena Sheethal Dsouza10 \\ ${ }^{1}$ Department of Conservative Dentistry and Endodontics, A.B. Shetty \\ Memorial Institute of Dental Sciences, Nitte (Deemed to be \\ University), Mangalore, Karnataka, India \\ 2 Public Health Dentistry Fr. Mullers Charitable Institutions, \\ Mangalore, Karnataka, India \\ J Health Allied Sci ${ }^{\mathrm{NU}} 2022 ; 12: 175-178$.
}

Mithra N. Hegde ${ }^{1}$ Kelvin Peter Pais ${ }^{2}$

Address for correspondence Teena Sheethal Dsouza, MDS, Department of Conservative Dentistry \& Endodontics, A.B. Shetty Memorial Institute of Dental Sciences, Nitte (Deemed to be University), Mangalore 575018, Karnataka, India (e-mail: tinsha_7@hotmail.com).
Abstract
Keywords
- COVID-19
- dentistry
- e-learning
- India

The sudden outbreak of the coronavirus disease 2019 pandemic has compelled universities worldwide to implement strategies for resuming academic courses by transferring some courses to a virtual modality. e-Learning has provided an excellent platform for education during this crisis. This review article discusses the various aspects of e-learning process that have to be considered before implementation, and the strengths and flaws of online education during this pandemic. It also sheds light on the necessary actions required to enhance the efficiency of e-learning in the future.

\section{Introduction}

Our world has suddenly been still with the outbreak of the coronavirus disease 2019 (COVID-19) pandemic. ${ }^{1}$ Amid the lockdowns and social distancing measures, one of the critical problems that the educational institutions faced was keeping the learning process going on, by rearranging the academic calendar and creating a new system of learning curriculum. ${ }^{2}$ During this confused turmoil, most education systems in the world turned toward the conveyance of education via the Internet or web-based learning. ${ }^{1}$

Compared to traditional brick and mortar classroom learning, e-learning in India is transforming at a quick pace. Until the last century, the education system in India did not allow students to participate in interactive sessions. With the evolution of digital learning in 2002, the students were able to cope with the concepts globally; the teaching has become easier for students and teachers. ${ }^{3}$ However, there remains a question of whether India is ready for this switch in terms of its infrastructure and students' digital readiness. ${ }^{1}$ Is online learning a boon or bane to the education system in this pandemic era? ${ }^{4}$

\section{The Essentials of e-Learning in Health-Care Professionals}

The education of health-care professionals in the age of the Internet requires a fundamental change to satisfy the demands of the learning patterns of the learners. ${ }^{5}$ The application of information and communications technology in education includes a wide array of usage from displaying written text pages on a computer screen to sophisticated use of virtual environments in the simulation of clinical cases. ${ }^{6,7}$ The literature on the impact of e-learning on dental education has been incorporated under the following sections: (1) role of administrators and information technology (IT) specialists, (2) students' response and perception, (3) teachers experience.

\section{Institutional Level: Role of IT Specialists and Administrators}

Computer-assisted learning or e-learning has progressively been used in dental curricula to support traditional classroom teaching and learning methods in various forms, such as web-based tutorials or discussion groups, theory lectures,
DOI https://doi.org/ 10.1055/s-0041-1731862. ISSN 2582-4287.

\footnotetext{
(C) 2021. Nitte (Deemed to be University). All rights reserved. This is an open access article published by Thieme under the terms of the Creative Commons Attribution-NonDerivative-NonCommercial-License, permitting copying and reproduction so long as the original work is given appropriate credit. Contents may not be used for commercial purposes, or adapted, remixed, transformed or built upon. (https://creativecommons.org/ licenses/by-nc-nd/4.0/)

Thieme Medical and Scientific Publishers Pvt. Ltd., A-12, 2nd Floor, Sector 2, Noida-201301 UP, India
} 
computerized patient simulations, and virtual reality-based simulations. $^{8}$

The year 2020 saw most Indian dental institutions continuing the learning process using e-learning. The universities that had already implemented web-based learning through online teaching methods could smoothly keep the e-learning. However, the execution of advanced IT in dental education remains a slow and tedious process. The administrators had to hire IT specialists to enforce e-learning to create web pages. Multiinstitutional trials, expertise in software development, ongoing technical support to provide necessary updates, and long-term financial support was another concern. Moreover, the hallmark of dental education still boils down to human contact with faculty members mentoring dental students and passing on the clinical skills needed to deliver excellent dental care. ${ }^{9}$

\section{Students Response and Perception}

Students' appraisal of the tools and value of online learning and evaluation of their attitudes are important factors that are essential to judge the success of any online learning system. ${ }^{10} \mathrm{~A}$ study conducted by Moshabab A. Asiry in 2017 regarding dental students' perception of online learning concluded that overall student attitudes were positive regarding online learning. The students viewed online learning helpful as a supplement to their education rather than a replacement for traditional teaching methods. With possession of necessary computer skills and access to the Internet, 59.2 and $64.8 \%$ of the students replied that online lectures and procedural videos were helpful to their learning. ${ }^{11}$

A descriptive quantitative study conducted in Delhi used a modified questionnaire to examine the students' perception and readiness about the online-learning system adopted at the university level during the ongoing pandemic. The study showed students' positive perception toward e-learning, which proves acceptance of this new learning system. ${ }^{12}$ However, contrary to this study, another qualitative research by Samra et al for undergraduate dental students showed a little diffident perspective toward the implementation of online learning. Nevertheless, the students were optimistic of engaging in online learning after ad-libbing in the future syllabus. ${ }^{13}$

\section{Teachers Experience}

The role of educators is also critical in the successful adoption of learning technologies. The faculty time, efforts, and requisites of IT skills are some of the teachers' concerns regarding online teaching. Colleges and universities must address the need to assist faculty members in their efforts to integrate technology into instruction by holding training programs regarding the use of online tools. ${ }^{14}$

\section{Essentials of Dental Education}

The essentials of dental education (-Fig. 1) comprise (a) theory lectures, (b) laboratory/simulation training, and (c) clinical skill training. Theory learning can be easily attained through online platforms. There are different systems available on the Internet such as Zoom Meetings, Google Hang-

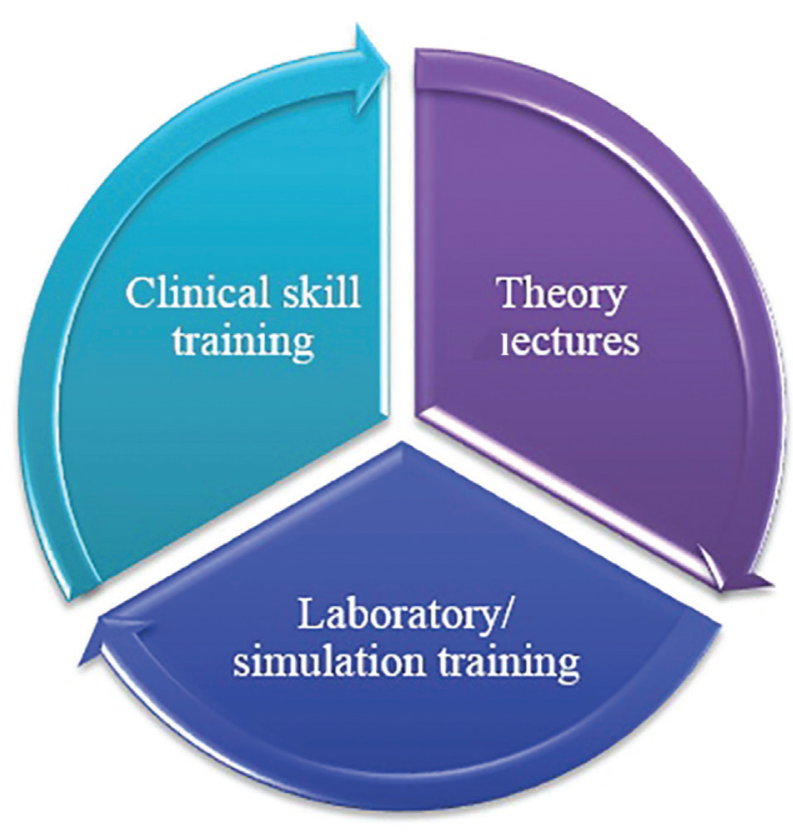

Fig. 1 Essentials of dental education.

outs, and Google Meet for online learning. Some universities have also created new online platforms for continuing the curriculum. An Indian questionnaire study by Samra et al involving undergraduate dental students concluded that $81 \%$ of the students used Zoom for their online lectures, whereas $2 \%$ of the students also reported the use of portals such as Microsoft Teams, Google Hangouts, and WebEx. The second essential is the laboratory training that includes practicing on the simulation models such as phantom heads. This can be carried out using digital or virtual reality techniques. But currently, there seems to be a lack of such facilities. The most crucial component of dental education, that is, clinical skill training, is the most difficult to consider in a pandemic environment. For clinical learning, students need to be in contact with patients. ${ }^{13}$

\section{Strengths of Online Learning in India during the COVID-19 Pandemic}

Someone has aptly said that the learning process should not be interrupted at a time of crisis. The information and communications technology department that has enabled and facilitated online learning has ensured that the learning process has been at a steady pace even now. The curriculum has been rearranged in most universities so that students have not fallen back into the learning schedule. Several elearning websites are created and upgraded that can be accessed by the students and teachers. ${ }^{4}$

Another additional strength is that the retention of information procured through online learning is more compared to traditional classroom teaching. ${ }^{4}$ This is because the learning process is faster. The time required to obtain information reduces. The freedom of learning at your own pace, rereading the study matter online, and skipping the concepts that are not essential are the benefits that the students can gain 
through this virtual platform. ${ }^{15-17}$ The added advantage was the lockdown curfew imposed throughout the country, which ultimately forced the students to remain at home and attend the online lectures and tests.

The ease and comfort of studying from home create a motivating and stimulative studying environment. ${ }^{18-20}$ Health professionals, who were busy with the clinical/hospital duties, could make use of this platform with minimum stress. ${ }^{21}$ The need to dress up and commute was also avoided.

A quantitative study by Khan et al revealed the highest response rate to the modified online questionnaire from the university students was 73.4\% concerning "Ease and Quick Share of Educational Material." It showed that through the medium of e-learning, the instructor and learner could easily and quickly share the educational material. ${ }^{12}$ A virtual platform creates an active learning environment with a better focus on teacher-student and student-student interaction. The discussion forums are an additional advantage for the students who are hesitant to clarify their doubts about the topic in a classroom. It provides an opportunity for a less pressured environment. Also, classroom-based "introverts" behave more like extroverts and are quite active when involved in online discussion forums. ${ }^{22}$

Adding to ease and comfort, the lessons provided on the learning websites can be viewed anytime. The lectures that are taken online could be heard and seen again and again if the student did not fully understand the topic. ${ }^{19}$ Some of the universities have their teaching platform online, which the students could make better use of.

The need for a structural edifice of roof and walls, distribution of study materials, and use of electric and water resources are minimized when online learning is considered for a large group of students. The cost of providing education seemed to be quite affordable. The money spent on travel was also saved. ${ }^{23}$

\section{Flaws of Online Learning during the COVID- 19 Pandemic}

In a developing country like India, many are unaware of the complexity of networking systems. Especially in rural areas, the provision for a computer/laptop with Internet connectivity is inadequate. This might lead to a competitive disadvantage compared to those who contact advanced technology in several different settings. Most of the low-income or middle-income population cannot afford the requisites needed for online learning. Also, the varying understanding of web-based learning in different age groups is a matter of concern. ${ }^{24}$ Connectivity/network issue was reported by most students (59.6\%) as a major drawback in a cross-sectional study conducted by Acharya et al in 2021 on 130 undergraduate dental students in Bhubaneswar, India. ${ }^{25}$

The willingness of students to benefit from the online learning program is also essential. Without a computer or proper connectivity in their residential area, the students will gradually become disinterested in this type of learning. ${ }^{26}$

Though e-learning is quite interactive, the feel of human interaction is entirely missing. Students may take the learn- ing for granted as there is no close monitoring of their activities. Also, the teachers are unable to control the attention of the students during the learning process. ${ }^{27}$ The supervision of the active participation of students in online learning is a downside. Opportunities for distraction may come in the form of work, family, or social responsibility. Moreover, the Internet itself can be a huge obstruction to learning. The option of switching between other open programs, such as gaming, listening to music, and browsing through other websites, can hinder the learning process. ${ }^{23}$

Team effort is essential when developing a useful online learning tool. It starts from the e-learning technical aspects to creating course pages for the institution's various programs and coordinates the plan of action with the faculty and the students. ${ }^{28}$ The instructor/teachers may have different levels of creativity and technical knowledge, and this may create differences in the teaching pattern for the students. ${ }^{29}$

Student evaluation is also of utmost importance. Most of the assessments carried out during this pandemic have been in the form of tests and quizzes. Multiple choice questions and true/false options cannot judge a students' depth of knowledge about a subject. Online tests in the form of typing the text answers cannot be implemented because the typing skills also differ among the students. ${ }^{23}$

Professional education has been quite affected by the lockdown. Though the students have benefitted from the teaching of the use of clinical skills via e-learning, implementation and practice of these skills have been lacking. There remains an inadequacy for developing practical skills through online education. ${ }^{11,30}$ Though some medical educators have been enthusiastically embracing the use of virtual patients, its effectiveness in dentistry is not known. Dental skills have to be practiced on phantom heads and live patients for practical skill improvement.

\section{Necessary Actions to Enhance the Efficiency of e-Learning}

- Implementation of e-learning at every university level with well-equipped latest technologies. The perception of inferior IT services could reduce a particular school's applicant pool. Educational technology must be utilized in a way that is learner and user-centered.

- Promoting scientific and practical level of students and staff in the use of e-learning methods.

- Encouraging educational staff for valuing new educational methods and devoting at least a part of the educational program for it. ${ }^{31}$

- Creating standardized patients for measuring competency by use of virtual patients. ${ }^{32}$ Virtual patients, as defined by the American Association of Medical Colleges, are "a specific type of computer program that simulates real-life clinical scenarios; learners emulate the roles of health-care providers to obtain history and conduct a physical exam, and make diagnostic and therapeutic decisions." Its advantages include flexibility in terms of space and pace for the learner, as well as a high potency of teaching reproducibility. Patient cases are 
standardized and cost-effective and a lecturer or an auditorium is no longer necessary. ${ }^{33}$

\section{Conclusion}

Online learning is altering the face of dental education in this pandemic situation. India faces a lot of challenges in terms of delivering education during these times. There certainly needs a lot of improvisation in technology, training of faculty in using online resources, availability of Internet connectivity for both the students and the teachers, and many more. ${ }^{34}$ Although online technology is known to many, certain constraints to its use and application still exist. It will not be responsible for irremediably changing the face of education. ${ }^{4}$

Conflict of Interest

None declared.

\section{References}

1 Bhandari B, Jain C, Sahu AK. Is e-learning the best bet during lockdown? The Hindu 2020

2 Covid-19: Keeping children learning during lockdown. Council of British International Schools Accessed at https://www.cobis.org.uk/blog/covid-19-keeping-children-learning-during-lockdown

3 Monica Malhotra KandhariE-Learning is transforming the face of education in IndiaBW Businessworld; 2018

4 Gupta M. E-learning: boon to education system during Covid-19 lockdown. India Today 2020 Apr

5 Rovai AP. Facilitating online discussions effectively. The Internet and Higher Education 2007;10(01):77-88

6 Choules K. Social change education: context matters. Adult Education Quarterly 2007;57(02):159-176

7 Huwendiek S, De leng BA, Zary N, Fischer MR, Ruiz JG, Ellaway R. Towards a typology of virtual patients. Med Teach 2009;31(08): 743-748

8 Santos GN, Leite AF, Figueiredo PTet al.Effectiveness of E-learning in oral radiology education: a systematic review. J Dent Educ 2016;80(09):1126-1139

9 Hillenburg KL, Cederberg RA, Gray SA, Hurst CL, Johnson GK, Potter BJ. E-learning and the future of dental education: opinions of administrators and information technology specialists. Eur J Dent Educ 2006;10(03):169-177

10 Turkyilmaz I, Hariri NH, Jahangiri L. Student's perception of the impact of E-learning on dental education. J Contemp Dent Pract 2019;20(05):616-621

11 Asiry MA. Dental students' perceptions of an online learning. Saudi Dent J 2017;29(04):167-170

12 Khan MAVivek, Nabi MK, Khojah M, Tahir M. Students' perception towards E-learning during COVID-19 pandemic in India: an empirical study. Sustainability 2021;13:57. Doi: 10.3390/su13010057

13 Samra RK, Nirola A, Verma A, Nagpal A, Thakur M. Dental students' perception on the impact of E-learning in continuing dental education during the current pandemic scenario. Indian J Dent Sci 2021;13:61-72

14 Dalmolin A, Mackeivicz G, Pochapski M, Pilatti G, Santos F. Learning styles preferences and e-learning experience of undergraduate dental students. Rev Odontol UNESP 2018;47:175-182

15 Andrews KG, Demps EL. Distance education in the U.S. and Canadian undergraduate dental curriculum. J Dent Educ 2003; 67(04):427-438

16 Li C. Farah lalani. The COVID-19 pandemic has changed education forever. This is how. World Economic Forum $2020 \mathrm{Apr}$
17 Weiner C. Key ingredients to online learning: adolescent students study in cyberspace - the nature of the study. Int J E-Learn 2003;2 (03):44-50

18 Isabelle Clover. Advantages and disadvantages of eLearning. elearning Industry. 2017. Accessed at: https://elearningindustry.com/advantages-and-disadvantages-of-elearning

19 Cook DA, Thompson WG. Comfort and experience with online learning: trends over nine years and associations with knowledge. BMC medical education 2014;14(01):1-5

20 McCord L, McCord RN Walter. Online learning: getting comfortable in the cyber class. Teach Learn Nurs 2010;5(01):27-32

21 Downing KJ, Lam T, Kwong T, Downing W, Chan S. Creating interaction in online learning: a case study. ALT-J Res Learn Technol 2007;15(03):201-215

22 Online training benefits during the coronavirus pandemic. American Safety Council. 2020. Accessed at: https://www. americansafetycouncil.com/articles/online-training-benefits.aspx

23 Appana S. A review of benefits and limitations of online learning in the context of the student, the instructor and the tenured faculty. Int J E-Learn 2008;7(01):5-22

24 Flye A, Gibson G, Seemann E, Wilkinson L. Technology as a developmental influence. In Crawford C, Willis DA, Carlsen R, et al. eds. Proceedings of Society for Information Technology and Teacher Education International Conference 2002. Nashville, TN. Chesapeake, VA: Association for the Advancement of Computing in Education; 2002:2511-2512

25 Acharya S, Ematty TB, Acharya S. The role of online teaching among the undergraduate dental students during the current COVID-19 pandemic in India: a pilot study. Pesqui Bras Odontopediatria Clin Integr 2021;21:e0129. Doi: 10.1590/pboci.2021.045

26 Sulcic V, Lesjak D. Students' readiness for online distance education in Slovenia. In Richards G, ed. Proceedings of World Conference on E-Learning in Corporate, Government, Healthcare, and Higher Education 2002. Montreal, QB, Canada. Chesapeake, VA: Association for the Advancement of Computing in Education; 2002:922-928

27 Rodriguez-Ardura I, Meseguer-Artola A. E-learning continuance: the impact of interactivity and the mediating role of imagery, presence and flow. Inf Manage 2016;53:504-516

28 Eachempati P, Ramnarayan K. Ten maxims for out of class learning to outclass the academic challenges of COVID-19. MedEdPublish 2020;9:1-10

29 Knight J, Bermant B. Profession or vocation? The changing roles of college faculty. In: Crawford C, Willis DA, Carlsen R, et al. eds. Proceedings of Society for Information Technology and Teacher Education International Conference 2002. Nashville, TN. Chesapeake, VA: Association for the Advancement of Computing in Education; 2002:606-607

30 Gormley GJ, Collins K, Boohan M, Bickle IC, Stevenson M. Is there a place for e-learning in clinical skills? A survey of undergraduate medical students' experiences and attitudes. Med Teach 2009;31 (01):e6-e12

31 Hosseini S, Aghbali A, Emamverdizadeh P, Hasani A, Razbani M. Using E-learning in teaching the quality of the practical oral pathology on dentistry students. Research and Development in Medical Education. 2014;3:61-65

32 Zary N, Johnson G, Fors U. Web-based virtual patients in dentistry: factors influencing the use of cases in the Web-SP system. Eur J Dent Educ 2009;13(01):2-9

33 Seifert LB, Socolan O, Sader R, Rüsseler M, Sterz J. Virtual patients versus small-group teaching in the training of oral and maxillofacial surgery: a randomized controlled trial. BMC Med Educ 2019;19(01):454. Doi: 10.1186/s12909-019-1887-1

34 Mathivanan SK, Jayagopal P, Ahmed S, et al. Adoption of E-learning during lockdown in India. Int J Syst Assur Eng Manag. 2021 s13198-021-01072-4 